\title{
Strategi Komunikasi Bisnis Kewirausahaan Eco Pesantren Daarut Tauhiid
}

\author{
Arum Ningsih*, Asep Muhyiddin, \& Imron Rosyidi \\ Prodi Komunikasi dan Penyiaran Islam, Program Pascasarjana, \\ UIN Sunan Gunung Djati, Bandung \\ *Email : arumningsib@gmail.com
}

\begin{abstract}
This study examines the process of conveying information on the persuasion process and evaluation in business communication on entrepreneurship in Eco Pesantren Daarut Taubiid. This research uses a case study method with a qualitative approach. The theory used is the diffusion of innovation and the AID $A$ model related to attention, interest, desire, and action. This study also uses a SWOT analysis (strength, weakness, opportunity, and threat). The results showed, information delivery was carried out with friendliness, simplicity, suitability, and connectedness. The persuasion process is characterized by kindness and strength which is reflected in the characters of discipline, courage, honesty, sincerity, toughness, and ketawadhuan. Innovations in entrepreneurship in Eco Pesantren Daarut Taubiid include communicative bamboo dormitories, profit sharing in the agribusiness system, and storage of merchandise in collective stalls. The evaluation carried out in the Daarut Taubiid Eco Islamic Boarding School's entrepreneurship uses a SWOT analysis that captures the main strengths and weaknesses in the Daarut Taubiid Eco Islamic Boarding School's entrepreneurship, and describes the opportunities and threats faced.
\end{abstract}

Keywords: strategy; business communication; entrepreneurship

\begin{abstract}
ABSTRAK
Penelitian ini mengkaji proses penyampaian informasi persuasi, dan evaluasi dalam komunikasi bisnis pada kewirausahaan Eco Pesantren Daarut Tauhiid. Penelitian ini menggunakan metode studi kasus dengan pendekatan kualitatif. Teori yang digunakan difusi inovasi dan model AIDA yang berkaitan dengan attention (perhatian), interest (minat), desire (hasrat), dan action (tindakan). Penelitian ini juga menggunakan analisis SWOT (strength, weakness, opportunity, dan threat). Hasil penelitian menunjukkan, penyampaian informasi dilakukan dengan keramahan, kesederhanaan, kesesuaian, dan keterhubungan. Proses Persuasi diwarnai corak kebaikan dan kekuatan yang tercermin dalam karakter kedisiplinan, keberanian, kejujuran, keikhlasan, ketangguhan, dan ketawadhuan. Inovasi dalam kewirausahaan Eco Pesantren Daarut Tauhiid meliputi asrama bambu yang komunikatif, bagi hasil dalam sistem agrobisnis, dan penitipan barang dagangan dalam warung kebersamaan. Evaluasi yang dilakukan dalam kewirausahaan Eco
\end{abstract}


A. Ningsih, A.Muhyiddin, \& I.Rosyidi

Pesantren Daarut Tauhiid menggunakan analisis SWOT yang menangkap kekuatan dan kelemahan utama yang ada di dalam kewirausahaan Eco Pesantren Daarut Tauhiid, serta menggambarkan peluang dan ancaman yang dihadapi.

Kata Kunci : strategi; komunikasi bisnis; kewirausahaan

\section{PENDAHULUAN}

Komunikasi menjadi pusat nadi di semua lini dan tingkat manajemen. Tanpa keterampilan berkomunikasi, akan sulit mengemukakan pikiran, meyakinkan pihak lain, bahkan bernegosiasi dengan baik. Dunia bisnis pun diwarnai seni berkomunikasi. Keterampilan berkomunikasi membangkitkan inspirasi dalam proses adu argumentasi, juga meraih sukses dalam penjualan. Munculnya masalah dalam bisnis, umumnya berawal dari kegagalan proses komunikasi.

Mustahil ada bisnis yang dilakukan tanpa komunikasi (Priyatna dan Ardianto, 2009: iii). Bahkan, saat pertukaran barang dan jasa masih menggunakan barter, komunikasi bisnis sebenarnya juga telah dilakukan. Perkembangan industri, teknologi, perdagangan dan telekomunikasi, menyebabkan komunikasi bisnis berkembang dengan cepat.

Perkembangan komunikasi bisnis juga diwarnai oleh difusi inovasi. Tujuan utama dari difusi inovasi adalah diadopsinya suatu inovasi (ilmu pengetahuan, teknologi, bidang pengembangan masyarakat) oleh anggota sistem sosial tertentu. Sistem sosial dapat berupa individu, kelompok informal, organisasi sampai kepada masyarakat.

Difusi inovasi dikaji, karena Komunikasi selama ini sering dipelajari lebih terfokus kepada arus komunikasi satu arah. Seiring perkembangan zaman, komunikasi dua arah antara pelaku usaha dan bisnis semakin pesat. komunikasi bisnis juga dipercepat perkembangan teknologi yang luar biasa.

Sektor kehidupan bisnis lainnya berkaitan dengan perpaduan komunikasi top down dan bottom up (Priyatna dan Ardianto, 2009: 11). Selama ini konsumen hanya dianggap pasif menerima saja berbagai informasi dan komunikasi yang datang dari perusahaan. Inilah paradigma komunikasi yang disebut model komunikasi linier. Komunikasi berkembang dengan model sirkuler, konvergen atau interaktif. Jika sebelumnya, konsumen yang dianggap butuh perusahaan, sekarang perusahaanlah yang butuh konsumen.

Perubahan-perubahan sosial dalam dunia usaha dan bisnis, memberikan tantangan baru bagi para pelaku bisnis. Tantangan ini menjadi peluang terciptanya inovasi-inovasi bisnis. Produk dari inovasi tersebut disebarkan dengan strategi komunikasi bisnis yang efektif.

Strategi komunikasi bisnis tidak hanya dibutuhkan pada perusahaanperusahaan, tetapi juga pada kewirausahaan pesantren. Kewirausahaan adalah padanan kata dari entrepreneurship dalam bahasa Inggris, unternebmer dalam bahasa Jerman, ondernemen dalam bahasa Belanda, sedangkan dalam bahasa Indonesia disebut kewirausahaan (Hendro, 2011: 29). 
Kata entrepreneur berasal dari bahasa Perancis, yaitu entrepreneur yang berarti petualang, pengambil resiko, kontraktor, pengusaha (orang yang mengusahakan suatu pekerjaan tertentu), dan pencipta yang menjual hasil ciptaannya (Hendro, 2011: 29). Kewirausahaan merupakan sebuah proses untuk menghasilkan suatu nilai tambah, menghasilkan nilai yang lebih tinggi. Kewirausahaan merupakan keterampilan dan seni membangun inovasi. Pada perkembangannya, kewirausahaan juga dipraktekan di pesantren.

Pesantren merupakan lembaga pendidikan yang mempunyai sejarahpanjang dan unik. Secara historis, termasuk pendidikan Islam yang paling awal dan masih bertahan sampai sekarang. Berbeda dengan lembagapendidikan yang muncul kemudian, pesantren telah sangat berjasa menceta kkader-kader ulama, dan kemudian berperan aktif dalam penyebaranagama Islam dan transfer ilmu pengetahuan (Nata, 2001: 101).

Pesantren di tengah perkembangan masyarakat memiliki tantangan untuk mewujudkan dakwah kahartos jeung karaos (dimengerti dan dirasakan). Perbaikan masyarakat tidak cukup hanya dengan ceramah melainkan juga pada kesejahteraan umat. Selama ini dakwah masih dimaknai sebatas lisan melalui pegajian ataau ceramah. Padahal, di kala masyarakat lapar, maupun kekurangan, mereka tidak sebatas membutuhkan ceramah saja.

Dakwah Islam memang bisa mudah dimengerti tapi belum bisa dirasakan. Misalnya, dalam sebuah musibah para ustadz mengimbau agar umat bersabar, bersabar, dan bersabar. Sementara para pendeta sangat giat menebar kebaikan dirasakan.

Dakwah kahartos jeung karaos menjadi motif dari berdirinya Eco Pesantren Daarut Tauhiid. Misi tersebut diwujudkan melalui pembentukan kewirausahaan pesantren. Kewirausahaan yang dibentuk bekerjasama dengan masyarakat sekitar. Oleh karena itu, masyarakat pun merasakan keuntungan yang dapat diperoleh dari berwirausaha bersama pesantren. Setelah merasakan kesejahteraan dari kerjasama dengan pesantren, masyarakat juga memperdalam agama ke pesantren. Pengajian dibentuk berdasarkan inisiatif masyarakat sendiri. Hasilnya, masyarakat ke pesantren untuk mengaji dan berwirausaha.

Penelitian yang dilakukan terhadap Eco Pesantren Daarut Tauhiid berkenaan dengan bagaimana strategi komunikasi bisnis dalam pengembangan kewirausahaan pesantren. Beberapa literatur yang ada korelasinya dengan tema penelitian yang dikaji dalam tesis ini, yaitu: Penelitian Agus Susanto berjudul Sistem Pembiayaan Bayt Maal wa Tamwil (BMT) Daarut Taubiid dalam Membantu Mengembangkan Potensi Ekonomi Pengusaha Kecil (Susanto, 2002). Pembahasannya tentang penanggulangan praktek-praktek monopoli ekonomi oleh tengkulak di sekitar Geger Kalong. Kondisi tersebut diperkeruh dengan kehadiran rentenir. Penanggulangan kondisi ekonomi tersebut dilakukan dengan adanya Sistem Pembiayaan Bayt Maal Wa Tamwil (BMT) Daarut Tauhiid dalam Membantu Mengembangkan Potensi Ekonomi Pengusaha Kecil.

Witri Cahyati (2009) meneliti tentang Strategi Komunikasi Pemasaran Industri Jilbab Cicalengka. Penelitian mengambil topik pengamatan terhadap fenomena 
jilbab dari sudut pandang pemasarannya. Tujuan penelitian untuk mengetahui, mendeskripsikan, dan menganalisis aktivitas komunikasi pemasaran yang dilakukan para pemasar jilbab. Objek penelitian ini para pemasar jilbab di Pasar Tanah Abang Jakarta yang berasal dari Cicalengka Bandung. Metode penelitian yang digunakan yaitu studi fenomenologi. dengan jenis penelitian kualitatif. Data diperoleh dari hasil wawancara. Penelitian didukung juga dengan beberapa data dari studi pustaka, dokumentasi dan observasi. Data yang diperoleh dijelaskan secara kualitatif. Hasil penelitian menunjukan tiga konsep diri pemasar jilbab, yaitu: 1) pemasar sebagai penjual jilbab, 2) pemasar sebagai pengusaha jilbab, dan 3) penjual sebagai bos usaha jilbab. Tujuan utama pemasaran berupa penghasilan yang tinggi dari penjualan jilbab. Penjual juga memandang pemasaran jilbab sebagai upaya memasyarakatkan jilbab di kalangan muslimah. Terbentuk juga upaya mengembangkan potensi kewirausahaan konveksi lokal.

Penelitian Ine Anggraini (2012) yang berjudul Strategi Marketing Public Relations pada Festival Jajanan Bango (Studi Kasus PT Unilever di Sidoarjo). Penelitian ini dimaksudkan ingin mengetahui bagaimana proses strategy marketing public relations dalam mendukung komunikasi pemasaran Festival Jajanan Bango.

Berbeda dengan penelitian terdahulu kewirausahaan yang dikembangkan oleh Eco Pesantren Daarut Tauhiid dibagi menjadi tiga macam, yaitu: agrobisnis, isi ulang air mineral, dan catering. Agrobisnis menjadi wirausaha utama yang dikembangkan. Agrobisnis yang dikelola berupa perkebunan sayuran.

Kegiatan usaha pesantren ini diwarnai juga dengan komunikasi. Tanpa komunikasi, tidaklah mungkin dapat meyakinkan individu atau kelompok untuk mengenal, memahami, dan membutuhkan produk. Komunikasi efektif merupakan faktor utama dalam menciptakan bisnis yang kondusif.

Berdasarkan temuan informasi seperti yang tercantum diatas, maka tulisan ini akan mengungkapkan Untuk membatasi wilayah penelitian sesuai dengan uraian latar belakang masalah di atas, maka rumusan masalah penelitian ini mengenai strategi komunikasi bisnis pada kewirausahaan Eco Pesantren Daarut Tauhiid. Berdasarkan rumusan masalah penelitian tersebut maka identifikasi masalah penelitian yaitu bagaimana proses menyampaikan informasi dalam komunikasi bisnis pada kewirausahaan Eco Pesantren Daarut Tauhiid? bagaimana proses persuasi dalam komunikasi bisnis pada kewirausahaan Eco Pesantren Daarut Tauhiid? bagaimana inovasi dalam komunikasi bisnis pada kewirausahaan Eco Pesantren Daarut Tauhiid? dan bagaimana evaluasi dalam komunikasi bisnis pada kewirausahaan Eco Pesantren Daarut Tauhiid?

Metode yang digunakan dalam penelitian ini adalah metode studi kasus dengan pendekatan kualitatif. Studi kasus yang digunakan dalam penelitian ini dilakukan dengan mempelajari strategi komunikasi bisnis dalam kewirausahaan Eco Pesantren Daarut Tauhiid secara mendalam dan mendetail.

Secara spesifik, sumber data menurut cara perolehannya dibagi menjadi dua, yaitu : Sumber data primer, yaitu data yang diperoleh dari hasil wawancara dengan pengurus Eco Pesantren Daarut Tauhiid, dan sumber data 
sekunder, yaitu data yang diperoleh dari literatur-literatur yang didapat dari Eco Pesantren Daarut Tauhiid, seperti buku-buku, kliping, arsip, media online dan yang lainnya yang mendukung untuk dijadikan data sekunder. Data penelitian ini dikumpulkan melalui teknik observasi partisipan, wawancara kepada pengurus Eco Pesantren Daarut Tauhiid dan studi dokumentasi.

\section{HASIL DAN PEMBAHASAN}

Eco Pesantren Daarut Tauhiid terletak di Jl. Cigugur Girang No.33 Kp. Pangsor, Desa Cigugur Girang Kecamatan Parongpong Bandung Barat. Eco Pesantren Daarut Tauhiid secara legal berdiri sejak tanggal 6 Juni 2006.

Inti aktivitas di Daarut Tauhiid bergerak di bidang pendidikan, dakwah $\&$ sosial. Namun, sebagai sebuah pesantren, maka pada Eco Pesantren Daarut Tauhiid terdapat beberapa keunikan atau kekhasan dibandingkan pesantren lain pada umumnya. Salah satu diantaranya adalah tingginya intensitas aktivitas berwirausaha atau berbisnis di dalam lingkungan Eco Pesantren Daarut Tauhiid. Tingginya intensitas aktivitas berbisnis tersebut dapat dirasakan baik sejak awal masa pendirian maupun hingga saat ini.

Aktivitas berbisnis tanpa merusak lingkungan dipandang sebagai bagian atau bahkan nilai tambah dari garapan Eco Pesantren Daarut Tauhiid. Inilah latar belakang pemberian nama Eco Pesantren Daarut Tauhiid. Zaenal menjelaskan filosofi penyematan nama eco pada pesantren sebagai berikut:

Istilah eco, kita ambil dari kata ekologi yang berarti ilmu yang mempelajari interaksi organisme dan lingkungannya. Bagi Eco Pesantren Daarut Tauhiid, mencintai dan melestarikan lingkungan hidup sebenarnya sudah inheren dalam diri. Sebab, betapa banyak ayat Qur'an dan Hadis Nabi yang menerangkan pentingnya mencintai dan melestarikan lingkungan (Wawancara Zaenal, Koordinator Agrobisnis Eco Pesantren Daarut Tauhiid pada 20 Februari 2015).

Peran pondok pesantren dalam pelestarian lingkungan makin menemukan momentumnya tatkala pemerintah, dalam hal ini Kementerian Lingkungan Hidup (KLH), meluncurkan program Eco-Pesantrenpada 5 Maret 2008 di Asrama Haji Pondok Gede, Jakarta. Eco- Pesantren adalah suatu institusi pendidikan Islam yang mempunyai kepedulian pada aktivitas yang tanggap terhadap lingkungan hidup.

Usaha pesantren untuk membangun eco culture di daerah Kampung Pangsor, Desa Cigugur Girang, Kecamatan Parongpong, Kabupaten Bandung Barat ini pernah mendapatkan penolakan. Semula diajukan untuk kawasan perumahan dengan tema Eco Bamboo House. Tetapi, tidak mendapat izin dari pemerintah. Pihak pesantren tidak berhenti melangkah, sehingga mengajukan untuk kawasan pendidikan.Akhirnya, medapat izin dari pemerintah. Sistem yang dibangun bersifat building school, yakni perpaduan dari pendidikan pesantren dan Sekolah Menengah Atas (SMA) Khadimul Ummah Daarut Tauhiid. 
Tujuan yang mendorong Eco Pesantren Daarut Tauhiid untuk mendirikan kewirausahaan, yaitu; kemandirian finansial, pemberdayaan masyarakat, dan ketauhidan/ketuhanan.

\section{Proses penyampaian Informasi Kewirausahaan Eco Pesantren Daarut Tauhiid}

Aktivitas komunikasi bisnis yang dijalankan oleh Eco Pesantren Daarut Tauhiid dalam menjalankan bisnisnya antara lain: melalui pertama, Komunikasi dengan mitra bisnis. komunikasi dengan mitra bisnis dilakukan dengan keramahan dan kesederhanaan. Keramahan dalam proses menyampaikan informasi ditunjukkan dengan sikap murah senyum para karyawan Eco Pesantren Daarut Tauhiid.

Sikap ramah dibiasakan dalam penyambutan tamu dengan rumus $3 \mathrm{~S}$ senyum, salam, dan sapa. Memang setiap orang berbeda-beda kepribadiannya, ada yang ramah ada juga yang tidak. Tapi kami terus berusaha mengamalkan $3 \mathrm{~S}$ yang menjadi budaya pesantren. Senyum kan ibadah yang paling mudah. Salam juga tanda persaudaraan, kehangatan, dan perdamaian. Menyapa orang menunjukkan kita welcome kepada orang yang berkunjung (Husen Gani, Direktur Kewirausahaan Eco Pesantren Daarut Tauhiid. Wawancara pada 18 Juni 2015).

Keramahan dalam komunikasi dengan mitra bisnis yang dituturkan Husen Gani, menunjukkan jalannya komunikasi nonverbal dalam bisnis. Bentuk komunikasi yang paling mendasar dalam komunikasi bisnis adalah komunikasi nonverbal (nonverbal communications). Komunikasi nonverbal dalam bentuk keramahan ini di antaranya melalui (a) Senyum. Menurut penuturan Husen Gani di atas, bagi Eco Pesantren Daarut Tauhiid, senyum merupakan ibadah yang sederhana dan mudah dilakukan (Husen Gani, Direktur Kewirausahaan Eco Pesantren Daarut Tauhiid. Wawancara pada 18 Juni 2015). Sekalipun sederhana, dampak dari senyum dapat memberikan kesan yang mendalam. Semua karyawan di Eco Pesantren Daarut Tauhiid membiasakan diri menjadi pribadi yang murah senyum. Sebelum karyawan menggunakan kata-kata, mereka telah menggunakan gerakan-gerakan tubuh, bahasa tubuh (body language) sebagai alat untuk berkomunikasi dengan orang lain. Tersenyum dan berjabat tangan dengan orang lain untuk mewuiudkan rasa senang, simpati dan penghormatan. Komunikasi nonverbal karyawan Eco Pesantren Daarut Tauhiid melalui sebuah senyuman, dapat menggambarkan rasa senang, kasih sayang, dan persaudaraan. Komunikasi nonverbal dengan senyuman memperkuat komunikasi verbal bahwa karyawan senang dengan kunjungan mitra bisnis pesantren.

Salam dimaknai oleh pihak Eco Pesantren Daarut Tauhiid sebagai sambutan kehangatan untuk saling mendoakan (Husen Gani, Direktur Kewirausahaan Eco Pesantren Daarut Tauhiid. Wawancara pada 18 Juni 2015). Selain itu, salam juga dapat memberikan kedamaian serta kesejukan untuk yang menerimanya. Oleh karena itu, Eco Pesantren Daarut Tauhiid membudayakan keramahan melalui 
pengucapan salam. Komunikasi nonverbal dalam bentuk salam juga lebih bersifat spontan, dibandingkan dengan komunikasi verbal dalam mendoakan keselamatan pengunjung. Namun, komunikasi nonverbal melalui salam, memiliki pengaruh yang lebih besar daripada komunikasi verbal. Terutama dalam kaitannya dengan penyampaian perasaan dan emosi karyawan.

"Budaya menyapa tamu yang datang sudah menjadi kebiasaan Eco Pesantren Daarut Tauhiid.” (Husen Gani, Direktur Kewirausahaan Eco Pesantren Daarut Tauhiid. Wawancara pada 18 Juni 2015) Inilah keramahan karyawan Eco Pesantren Daarut Tauhiid, yang dilengkapi dengan kebiasaan menyapa. Menyapa orang memberikan kesan berbaik sangka, sehingga orang yang berkunjung ke Eco Pesantren Daarut Tauhiid merasa nyaman. Menyapa pengunjung juga memberikan dampak antusias pengunjung untuk menjadi mitra bisnis Eco Pesantren Daarut Tauhiid. Meskipun dapat berdiri sendiri, komunikasi nonverbal karyawan Eco Pesantren Daarut Tauhiid, sering kali berkaitan erat dengan ucapan (lisan). berarti sering terjadi penggabungan antara komunikasi verbal dan nonverbal dalam situasi berkomunikasi dengan mitra bisnis. Kata-kata yang disampaikan dalam menyapa, hanya membawa sebagian dari pesan verbal, sedangkan senyum, disampaikan melalui sinyal-sinyal nonverbal.

Kesederhanaan Eco Pesantren Daarut Tauhiid membuka peluang berwirausaha dengan mitra bisnis di manapun. Usman Hadi melukiskan kesederhanaan dalam berkomunikasi di Eco Pesantren Daarut Tauhiid seperti berikut.

Kesederhanaan alat komunikasi yang modern di Eco Pesantren Daarut Tauhiid berasal dari pemikiran yang canggih. Demikian juga dengan kesederhanan komunikasi melalui internet seperti email, mempermudah komuninkasi dengan mitra bisnis yang jauh. Kesederhanaan juga tercermin dari cara berpakaian karyawan, sistem kewirausahaan, dan penggunaan bahasa yang sederhana sehingga mudah dipahami. Keserhanaan inilah yang membuat Eco Pesantren Daarut Tauhiid mampu menyederhanakan masalah-masalah yang pelik bagi masyarakat. ${ }^{153}$

Penjabaran Usman Hadi ini, memperjelas kesederhanaan yang terlihat dari alat komunikasi modern di Eco Pesantren Daarut Tauhiid, berasal dari pemikiran yang canggih. Demikian juga dengan kesederhanan komunikasi melalui internet seperti email, mempermudah komuninkasi dengan mitra bisnis yang jauh.

Kesederhanaan juga tercermin dari cara berpakaian karyawan, sistem kewirausahaan yang dijalankan, dan penggunaan bahasa yang sederhana sehingga mudah dipahami. Keserhanaan inilah yang membuat Eco Pesantren Daarut Tauhiid mampu menyederhanakan masalah-masalah yang pelik bagi masyarakatKomunikasi bisnis bagi konsumen atau mitra bisnis, dapat memberitahu atau memperlihatkan kepada mereka tentang bagaimana dan mengapa suatu produk digunakan, oleh orang macam apa, serta di mana dan kapan. Komunikasi pemasaran berkontribusi menanamkan citra dalam ingatan dan mendorong penjualan. 
Bagi Eco Pesantren Daarut Tauhiid, membangun komunikasi yang baik dengan mitra bisnis sangat penting, sehingga mereka bisa mendapatkan mitra

Bisnis setia yang membantu mempromosikan produk yang mereka jual. Menariknya, bagi Eco Pesantren Daarut Tauhiid tidak membeda-bedakan pelayanan kepada mitra bisnis lama atau mitra bisnis baru. Bagi mereka semua sama harus dilayani dengan cara terbaik. Tidak ada yang paling diutamakan seperti kebanyakan pembisnis lain, memberikan kemudahan bagi mitra bisnis yang sudah memiliki hubungan emosional, misalnya dengan memberikan harga murah saat negosiasi suatu produk. Eco Pesantren Daarut Tauhiid menetapkan harga yang sama untuk siapa saja. Berikut penjelasan dari Usman Hadi.

Membina hubungan dengan mitra atau jaringan bisnis juga merupakan salah satu aktivitas komunikasi Eco Pesantren Daarut Tauhiid. Mitra bisnis adalah pihak-pihak yang terkait secara langsung dengan bisnis yang Eco Pesantren Daarut Tauhiid jalankan. Mitra bisnis adalah koneksi, atau orang-orang yang tergabung dalam suatu komunitas bisnis, marga, maupun kepercayaan (Usman Hadi, Kepala Divisi Dana Usaha Yayasan Eco Pesantren Daarut Tauhiid. Wawancara pada 12 April 2015).

Hubungan dengan mitra atau jaringan bisnis juga merupakan salah satu aktivitas komunikasi Eco Pesantren Daarut Tauhiid. Sebagaimana yang dijelaskan Usman Hadi, itra bisnis adalah pihak-pihak yang terkait secara langsung dengan bisnis yang Eco Pesantren Daarut Tauhiid jalankan. Mitra bisnis adalah koneksi, atau orang-orang yang tergabung dalam suatu komunitas bisnis, marga, maupun kepercayaan.

Mitra bisnis bagi Eco Pesantren Daarut Tauhiid akan memudahkan aktivitas bisnis mereka seperti membantu pemasaran produk barang dan jasa, arus masuk barang dan suplier, atau informasi yang berkembang seputar situasi bisnis terkini.

Sebelum proses penyampaian pesan dilakukan, Eco Pesantren Daarut Tauhiid sebagai pengirim pesan, menyiapkan ide atau gagasan bisnis yang ingin disampaikan kepada pihak lain. Bagi Eco Pesantren Daarut Tauhiid de dapat diperoleh dari berbagai sumber. Sebab dunia ini penuh dengan berbagai macam informaasi baik yang dapat dilihat, didengar, dibaui, dikecap, maupun diraba. Lebih lanjut Usman Hadi menjelaskan,

Ide-ide yang muncul dari Eco Pesantren Daarut Tauhiid disaring dan disusun kemudian digambarkan. Setiap karyawan sering memiliki ide yang berbeda, maka ide yang diambil berupa ide berdasarkan pengalaman (Usman Hadi, Kepala Divisi Dana Usaha Yayasan Eco Pesantren Daarut Tauhiid. Wawancara pada 12 April 2015).

Proses komunikasi dimulai dengan adanya ide dalam pikiran. Tidak semua ide dapat diterima atau dimengerti dengan sempurna. Oleh karena itu ide yang dimiliki Eco Pesantren Daarut Tauhiid diubah dalam bentuk kata- kata, ekspresi wajah, dan sejenisnya, kemudian disampaikan ke masyarakat sebagai mitra bisnisnya.

Agar ide dari Eco Pesantren Daarut Tauhiid dapat diterima dan dimengerti 
secara sempurna, Eco Pesantren Daarut Tauhiid memperhatikan beberapa hal, yaitu perwakilan pihak pesantren yang akan menyampaikan pesan, apa yang ingin disampaikan, maksud dan tujuan, audiens, gaya personal, dan latar belakang budaya. Sebagai contoh, Eco Pesantren Daarut Tauhiid menyampaikan pesan bisnisnya dengan menggunakan bahasa Sunda yang halus. Sikap menolak penawaran dan permintaan disampaikan secara tidak langsung. Eco Pesantren Daarut Tauhiid terlebih dahulu menggunakan kalimat- kalimat pembuka yang lebih netral, baru kemudian meyatakan sikap penolakan.

Setelah mengubah ide-ide ke dalam suatu pesan, tahap berikutnya menyampaikan pesan bisnis melalui berbagai saluran. Komunikasi antara Eco Pesantren Daarut Tauhiid dengan mitra bisnnisnya akan terjadi, jika sumber pesan (Eco Pesantren Daarut Tauhiid) mengirimkan pesan bisnis dan penerima (mitra bisnis) menerimanya. Sebagai contoh, saat Aa Gym menyampaikan ceramah tentang kejujuran dalam berbisnis, para pendengar sebagai audiens mendengarkan apa yang dikatakan dan memahami pesan-pesann yang disampaikan.

Setelah mitra bisnisnya menerima pesan, tahap berikutnya masyarakat sebagai mitra menafsirkan pesan bisnis tersebut. Pesan yang disampaikan Eco Pesantren Daarut Tauhiid mudah dimengerti dan tersimpan dalam benak pikiran masyarakat. Selanjutnya, pesan dari Eco Pesantren Daarut Tauhiid ditafsirkan secara benar sebagaimana yang dimaksud.

Umpan balik (feedback) menjadi penghubung akhir dalam mata rantai komunikasi bisnis pada kewirausahaan Eco Pesantren Daarut Tauhiid. Umpan balik tersebut merupakan tanggapan penerima pesan yang memungkinkan Eco Pesantren Daarut Tauhiid menilai efektivitas pesan bisnisnya.

Tanggapan masyarakan yang diterima Eco Pesantren Daarut Tauhiid meliputi verbal dan nonverbal, seperti penjelasan Usman Hadi di atas. Pada saat pihak Eco Pesantren Daarut Tauhiid melakukan aktivitas bisnis atau transaksi bisnis, maka akan terjadi pertukaran gagasan, pendapat, informasi, serta instruksi.

Komunikasi bisnis Eco Pesantren Daarut Tauhiid melibatkan pertukaran informasi yang terus-menerus. Aktivitas ini merupakan sebuah proses terusmenerus yang banyak menekankan aspek bisnis tersebut untuk menemukan cara komunikasi yang lebih efektif dengan para pekerja dan dengan mitra. Media komunikasi yang digunakan untuk berkomunikasi dengan mitra antara lain: tatap muka, pengajian, banner, brosur, telepon, Blacberry Messanger.

Kedua, Komunikasi antarkaryawan. Aktivitas komunikasi Eco Pesantren Daarut Tauhiid antarkaryawan di tempat usahanya, meliputi training karyawan dan memberikan pesan-pesan komunikasi, agar para karyawan mampu memperlakukan dan melayani mitra bisnis dengan baik. Eco Pesantren Daarut Tauhiid rata-rata berkomunikasi secara (tatap muka) dengan para karyawannya.

Proses penyampaian informasi dilakukan dengan kesesuaian dan keterhubungan. Kesesuaian dalam berpakaian. Di Eco Pesantren Daarut Tauhiid diwajibkan karyawan wanita menggunakan jilbab panjang dengan bawahan rok. Adapun karyawan laki-laki menggunakan celana katun dengan 
atasan kemeja, kaos berkerah, batik, atau koko.

Aturan berpakaian ini untuk kesesuaian citra yang dibangun pesantren sebagai pondok santri. Pakaian karyawan Eco Pesantren Daarut Tauhiid mengkomunikasikan pribadi yang islami, sehingga tidak ada pandangan masyarakat karyawan pesantren tapi pakaian tidak sopan.

Karyawan Eco Pesantren Daarut Tauhiid berhati-hati juga dalam menempatkan gaya berbicara yang digunakan antarkaryawan. Gaya bicara yang digunakan karyawan Eco Pesantren Daarut Tauhiid serasi dengan waktu berbicara, selain itu, selaras dengan kondisi dan situasi penyampaian informasinya.

Keterhubungan dilakukan ketika Karyawan Eco Pesantren Daarut Tauhiid beroperasi dalam jaringan kewirausahaan. Guna mencapai keberadaan yang dihormati, karyawan Eco Pesantren Daarut Tauhiid menjadikan pesantren mudah dihubungi. Antarkaryawan pun tidak mempersulit hubungan komunikasi. Ella yang menjadi admin d Eco Pesantren Daarut Tauhiid menuturkan sebagai berikut.

Intensitas komunikasi antara Eco Pesantren Daarut Tauhiid dengan karyawannya, relatif terjadi setiap hari baik ketika karyawan berada di lokasi bisnis atau di luar. Fenomena yang ditemui peneliti di lapangan bahwa sebagian banyak waktu Eco Pesantren Daarut Tauhiid tidak terlibat langsung dalam bisnisnya. Para karyawan mamppu menanganinya. Sehingga proses komunikasi pun terjadi setiap saat antarkaryawan. Ada saat-saat terjadi pembicaraan informal antara karyawan yang satu dengan karyawan yang lain untuk memantau pekerjaan.

Bagi para karyawan Eco Pesantren Daarut Tauhiid pembicaraan informal dipandang sebagai cara yang efektif untuk menyampaikan pesan. Pesan yang disampaikan oleh Eco Pesantren Daarut Tauhiid dengan karyawannya meliputi: mengajak agar bekerja dengan baik dan profesional, mengingatkan karyawan agar memperlakukan mitra bisnis dengan baik. Di samping itu, bagi Eco Pesantren Daarut Tauhiid menganggap komunikasi yang paling efektif dengan para karyawannya adalah komunikasi yang bersifat nonverbal atau simbolik.

Ada yang menarik dari komunikasi antarkaryawan Eco Pesantren Daarut Tauhiid di lingkungan bisnis. Komunikasi terjadi bukan hanya pada urusan atau aktivitas bisnis saja, melainkan juga pada urusan lain seperti mengingatkan karyawan untuk shalat, menanyakan kepada karyawan urusan kuliah atau pekerjaan di rumah dan lain sebagainya.

\section{c) Silaturahmi}

Silaturahmi menjadi salah satu proses komunikasi di Eco Pesantren Daarut Tauhiid.

\section{1) Berbagi sebagai Penguat Silaturahmi}

Berbagi merupakan tradisi yang dibiasakann di Eco Pesantren Daarut Tauhiid. Wadah yang dibentuk khusus untuk bebagi dinamakan Dompet Peduli Umat (DPU) Daarut Tauhiid. DPU ini menerima titipan zakat infak, dan sedekah. Berbagi dengan umat menguatkan tali silaturahmi yang dibentuk pesantren. Bagi pihak pesantren, silaturahmi dimaknai sebagai ibadah dan upaya 
menyambungkan tali kasih sayang.

Penjelasan Husen menegaskan aktivitas komunikasi Eco Pesantren Daarut Tauhiid, salah satunya dengan menjalin hubungan baik dengan mitra bisnisya secara informal melalui apa yang disebut dengan silaturahmi. Silaturahmi adalah bentuk komunikasi informal yang dilakukan oleh Eco Pesantren Daarut Tauhiid. Silaturahmi bisa terjadi secara langsung (tatap muka) atau secara tidak langsung melalu telepon. Komunikasi yang dilakukan seperti ucapan selamat hari raya, menanyakan kabar, mengobrol, menjaga hubungan pertemanan, dan sebagainya.

Eco Pesantren Daarut Tauhiid meyakini bahwa keutamaan dan bersilaturahmi sangat banyak.Bagi Eco Pesantren Daarut Tauhiid silaturahmi akan memanjangkan umur dan melapangkan rizki.

\section{Berdakwah sebagai Pengikat Silaturahmi}

Kegiatan berdakwah menjadi pengikat silaturahmi di Eco Pesantren Daarut Tauhiid. Komunitas dakwah dibentuk untuk membiasakan masyarakat menjaga kebaikan melalui berkumpul dengan orang-orang baik. silaturahmi dimaknai sebagai ibadah dan upaya menyambungkan tali kasih sayang.

Banyak orang yang terjerumus ke dalam lubang kemakisatan dan kesesatan karena pengaruh teman bergaul yang jelek. Namun juga tidak sedikit orang yang mendapatkan hidayah dan banyak kebaikan disebabkan bergaul dengan teman-teman yang shalih. Peran dan dampak teman berdasarkan hadits Rasulullah yang diamalkannya. Bagi Iwan, pemisalan teman yang baik dan teman yang buruk, ibarat seorang penjual minyak wangi dan seorang pandai besi. Penjual minyak wangi akan memberi minyak wangi, atau bisa membeli minyak wangi darinya, dan jika tidak, tetap mendapatkan bau harum darinya. Sedangkan pandai besi, bisa jadi (percikan apinya) mengenai pakaian, dan jika tidak, tetap mendapatkan bau asapnya yang tidak sedap. Oleh karena itu, adanya kepentingan untuk berkomunikasi dengan teman yang memahami agama.

Salah satu wadah komunikasi Eco Pesantren Daarut Tauhiid adalah komunitas dakwah atau kelompok kajian agama. Komunitas dakwah memang bukan komunitas bisnis, namun Eco Pesantren Daarut Tauhiid banyak mengambil manfaat dan sini tidak hanya berdampak baik untuk kesolidan bisnis, namun juga untuk menjaga tauhid masyarakat yang menjadi mitra bisnisnya.

\section{Proses Persuasi dalam Komunikasi Bisnis pada Kewirausahaan Eco Pesantren Daarut Tauhiid.}

Persuasi dalam kewirausahaan Eco Pesantren Daarut Tauhiid mengubah sikap, kepercayaan atau tindakan masyarakat untuk mencapai tujuan kewirausahaannya. Secara sederhana, Eco Pesantren Daarut Tauhiid menyampaikan pesan dengan cara yang membuat mitra bisnisnya merasa mempunyai pilihan dan membuat mereka setuju.

Proses persuasi di Eco Pesantren Daarut Tauhiid memformulasikan AIDA dengan karakter pesantren, yakni: kedisiplinan dan keberanian yang dapat 
menarik perhatian, kejujurandan keikhlasan yang dapat membangkitkan minat kerjasama, ketangguhan dan ketawadhuan yang dapat menarik hasrat untuk bermitra, serta kebaikan dan kekuatan yang dapat membujuk tindakan untuk bermitra.

\section{Kedisiplinan dan keberanian yang dapat Menarik Perhatian}

Eco Pesantren Daarut Tauhiid menarik perhatian masyarakat dengan menampilkan karakter yang disiplin dan berani. Disiplin tidak dapat dibentuk dengan cara instan. Disiplin di Eco Pesantren Daarut Tauhiid menjadi aktivitas yang dilakukan secara berulang-ulang hingga membentuk karakter kuat. Eco Pesantren Daarut Tauhiid mejauhkan kemalasan, disiplin dalam waktu, dan tidak menunda-nunda pekerjaan.

Karyawan Eco Pesantren Daarut Tauhiid bernama Husen Gani, menjelaskan bagaimana pesantren menarik perhatian dengan mencerminkan kedisiplinan. Disiplin dapat menarik perhatian masyarakat, karena masyarakat menyadari benar manfaat atas aktifitas yang sedang dilakukan akan membentuk kedisiplinan. Berkaitan dengan membentuk karakter disiplin, mari kita tengok bagaimana rakyat Jepang mempraktekannya. Bagi mereka terlambat tanpa keterangan akan membuat orang lain khawatir dan berpikir pada hal-hal buruk seperti kecelakaan, sakit atau ada halangan yang menyulitkan.

Penuturan Husen Gani menegaskan Eco Pesantren Daarut Tauhiid memulai disiplin dari hal-hal sederhana dan kecil tapi dilakukan secara konsisten. Bagi Eco Pesantren Daarut Tauhiid sengaja terlambat atau mengkingkari janji berarti menyakiti perasaan orang lain. Oleh karena itu, jika memang benar-benar tidak bisa menepati janji, pihak pesantren selalu memberi informasi. Jika sudah membuat janji maka sekuat tenaga berusaha untuk datang lebih cepat dari jadwal yang telah disepakati. Eco Pesantren Daarut Tauhiid juga berjuang untuk mencerminkan disiplin shalat berjamaah, membaca Al-Qur'an setelahnya, menunaikan puasa sunnah, dan bersedakah.

Kedisiplinan yang tercermin dari pesantren, memunculkan perhatian masyarakat. Eco Pesantren Daarut Tauhiid juga menarik perhatian dengan keberanian.

Keberanian Eco Pesantren Daarut Tauhiid merupakan kekuatan yang tersimpan dalam jiwa pesantren. keberanian mendorongnya maju untuk menunaikan tugas, baik tindakan maupun perkataan. Keberanian Eco Pesantren Daarut Tauhiid mencegah keburukan dan menyadari semua kemungkinan resiko yang akan diterima. Lebih lanjut, Husen Gani sebagai bagian dari Eco Pesantren Daarut Tauhiid menuturkan keberanian yang dicerminkan pesantren.

Keberanian adalah energi yang merubah angan-angan mewujudkan pesantren desa menjadi nyata. Para pemberani menyikapi risiko bukan sebagai halangan apalagi musuh. Tapi menjadikannya sebagai tantangan. Semakin tinggi tantangan, semakin mereka bersemangat. Adapun musuh utama dari keberanian bukanlah rasa takut. Karena takut adalah karater manusiawi yang dimiliki tiap insan. Musuh keberanian sesungguhnya adalah sifat malas. Sebab malas seperti 
kanker, yang bila didiamkan terlalu lama akan menjalar ke seluruh tubuh. Ia merontokan semangat, meruntuhkan harapan dan memupus cita-cita.

Keberanian Eco Pesantren Daarut Tauhiid untuk menjelajah ke desa ketimbang berleha-leha di kota. Sebab dengan menjelajah desa, mitra pesantren akan bertambah, pengalaman pesantren semakin luas dan matang. Pesantren lebih berani mengambil resiko. Muslim sejati adalah pemberani. Dengan begitu Eco Pesantren Daarut Tauhiid yang dihiasi dengan jiwa berani dapat meraih perhatian masyarakat.

Kejujuran dan Keikhlasan yang dapat Membangkitkan Minat Kerjasama. Kejujuran Eco Pesantren Daarut Tauhiid dalam arti berani untuk mengemukakan kondisi sebenarnya dari usaha yang dijalankan, dan mau melaksanakan kegiatan usahanya sesuai dengan kemampuannya. Kejujuran ini diperlukan karena dengan sikap tersebut cenderung akan membuat masyarakat mempunyai kepercayaan yang tinggi kepada Eco Pesantren Daarut Tauhiid sehingga mau dengan rela untuk bekerja sama dalam jangka waktu panjang ke depan.Karakter jujur bagi Eco Pesantren Daarut Tauhiidbukan hanya menjadi topeng. Lebih dari itu, kejujuran menjadi lambang dari kehormatan dan integritas yang terjaga dari Eco Pesantren Daarut Tauhiid.

Minat kerjasama dari masyarakat bukan karena nama besar Aa Gym, tetapi karena kejujuran pesantrennya yang terjaga. Menurut Ahmad kejujuran pesantren meneladani kejujuran Rasul yang tercermin saat berniaga. Jika berjanji, Rasulullah selalu menepati janji. Jika mengantarkan barang dagangan selalu tepat waktu dengan kualitas sesuai pesanan. Karena itu pelangganya tidak pernah merasa kecewa atau mengeluh.

Integritas dan tanggung jawab terhadap tiap transaksi diperlihatkan Eco Pesantren Daarut Tauhiid pada siapapun. Berkat kejujurannya, Eco Pesantren Daarut Tauhiid dapat membangkitkan minat bekerjasama dari masyarakat. Eco Pesantren Daarut Tauhiid berprinsip, sekali orang tidak percaya karena khianat maka selamanya tidak akan percaya lagi. Lebih sulit mengembalikan kepercayaan orang lain dari pada membangunnya.

Ikhlas bagi Eco Pesantren Daarut Tauhiid memiliki arti membersihkan. Lebih lanjut, keikhlasan untuk pesantren membersihkan hati supaya menuju kepada Allah semata. Dengan kata lain, ibadah baik yang sifatnya vertikal pada Allah SWT ataupun horizoltal pada sesama mahluk tidak diniatkan selain pada Allah.

Ikhlas menjadi pondasi penting dalam kewirausahaan Eco Pesantren Daarut Tauhiid. Pesantren mencerminkan niat, kewirausahaan yang dilakukan tulus karena Allah, bukan ingin mendapat pujian masyarakat. Peristiwa yang menurut masyarakat baik atau buruk bagi pesantren sama saja. Ada keuntungan dalam kewirausahaan tidak menjadi lupa diri, hilangnya keuntungan tidak membuat bersedih.

Keikhlasan yang dibangun pesantren mencerminkan ketulusan untuk bekerja sama dengan masyarakat. Oleh karena itu, bangkitlah minat bekerja sama 
A. Ningsih, A.Muhyiddin, \& I.Rosyidi

dari masyarakat.

\section{Karakter Tangguh dan Tawadhu yang dapat Menarik Hasrat untuk Bermitra}

Keberanian saja belum cukup untuk Eco Pesantren Daarut Tauhiid menarik hasrat masyarakat untuk bermitra, jika tidak dibarengi karakter tangguh. Berani yang berdiri sendiri, bila tidak hati-hati akan membuat semangat menggebu pada langkah awal namun kemudian berpotensi padam pada langkahlangkah selanjutnya begitu menghadapi rintangan. Mundur sebelum bertempur, menyerah sebelum berkelahi. Semangat bermitra dengan masyarakat menjadi berarti karena matang diuji.

Contoh ketangguhan Daarut Tauhiid terlihat saat popularitas AA Gym meredup di media massa, tetapi pesantren tetap berdiri. Ujian yang dihadapi kewirausahaan pesantren dihadapi sebagai tantangan. Akibatnya, pesantren menjadi tangguh, sehingga dapat melakukan pengembangan melalui eco pesantren.

Keberanian diiringi ketangguhan, membuat Eco Pesantren Daarut Tauhiid konsisten dalam menggapai tujuannya. Tangguh adalah simbol dari keuletan, kegigihan dan kesabaran pihak Eco Pesantren Daarut Tauhiid. Secara perlahan tapi pasti ketangguhan Eco Pesantren Daarut Tauhiid menarik hasrat masyarakat untuk bermitra.

Proses membujuk hasrat masyarakat untuk bermitra juga diwarnai dengan karakter tawadhu. Tawahdu menurut Eco Pesantren Daarut Tauhiid tidak memandang jika pesantren lebih baik dari masyarakat dan tidak memandang masyarakat lebih buruk dibanding pesantren.

Eco Pesantren Daarut Tauhiidbijak mengakui jasa dan kelebihan masyarakat. Bijak terhadap kekurangan dan kesalahan masyarakat. Eco Pesantren Daarut Tauhiidmembantu masyarakat agar sama-sama tumbuh lebih baik. Eco Pesantren Daarut Tauhiid juga terbuka untuk melihat kekurangan dan kesahalan pesantren. Instrospeksi pesantrenterus dilakukan.

Proses persuasi yang diwarnai ketangguhan dan ketawadhuan menarik hasrat masyarakat untuk bermitra. Karakter tawadhu pesantren dipertegas dengan menerima kebenaran dari siapapun. Pesantren tidak menyombongkan diri di tengah usaha persuasi masyarakat untuk bermitra. Oleh karena itu, tertariklah hasrat untuk bermitra dengan pesantren.

\section{Kebaikan dan Kekuatan yang Dapat Membujuk Tindakan untuk Bermitra}

Kebaikan melambangkan kearifan Eco Pesantren Daarut Tauhiid. Eco Pesantren Daarut Tauhiid melakukan pembenahan untuk perubahan ke arah yang lebih baik. Akblaqul karimah menjadi corak khas dalam persuasi yang dilakukan oleh Eco Pesantren Daarut Tauhiid.

Karakter kuat menjadi corak dari Eco Pesantren Daarut Tauhiid yang 
bersungguh-sungguh menggapai tujuan kewirausahaannya. Kekuatan akblaqul karimah sebagai tujuan berwirausaha tidak draih dengan berleha-leha. Tujuan berwirausaha pesantren untuk kemandirian finansial, pemberdayaan masyarakat, dan menjaga ketauhidan masyarakat, diperjuangkan oleh Eco Pesantren Daarut Tauhiid dengan segala kemampuan.

Kebaikan dan kekuatan yang diturunkan pada keberanian, kedisiplinan, kejujuran, keikhlasan, ketangguhan, dan ketawadhuan, dapat membujuk tindakan masyarakat untuk bermitra dengan pesantren.

Penyampaian pesan-pesan persuasif Eco Pesantren Daarut Tauhiid bertujuan untuk mempengaruhi masyarakat yang cenderung mempertahankan ide atau gagasannya. Sebagai akibatnya, pesan-pesan persuasif umumnya lebih lama, lebih rinci, dan tergantung pada perencanaan strategis yang cukup ketat.

Eco Pesantren Daarut Tauhiid dapat meyakinkan masyarakat segera di bagian permulaan bahwa mempunyai sesuatu yang berguna untuk disampaikan. Eco Pesantren Daarut Tauhiidperkenalkan kepada audiens dengan suatu masalah kewirauusahaan atau ide yang membuat mereka mau mendengar pesan-pesan yang akan sampaikan.

Eco Pesantren Daarut Tauhiid menjelaskan relevansi pesan-pesan dengan masyarakat. Eco Pesantren Daarut Tauhiid kembangkan pernyataan yang telah disampaikan pada fase pertama dengan agak rinci. Tujuan Eco Pesantren Daarut Tauhiid adalah bagaimana masyarakat mampu berpikir. Eco Pesantren Daarut Tauhiid hubungkan atau kaitkan pesan-pesan yang akan sampaikan dengan manfaat secara spesifik yang dapat dinikmati oleh masyarakat. Masyarakat memberikan keputusan untuk menggunakan produk Eco Pesantren Daaruut Tauhiid. Keputusan diambil karena adaya hasrat untuk menerima pesan-pesan persuasi yang disampaikan.

Eco Pesantren Daarut Tauhiid menyarankan tindakan spesifik yang dinginkan terhadap audiens. Selanjutnya, Eco Pesantren Daarut Tauhiid diingatkan kembali bagaimana audiens akan memperoleh manfaat dari tindakan yang akan dilakukan tersebut. Eco Pesantren Daarut Tauhiid mempermudah audiens untuk tindakan tersebut.

Pesan-pesan persuasif Eco Pesantren Daarut Tauhiid juga dimulai dengan melakukan analisis audiens, mempertimbangkan perbedaan budaya, dan memilih pendekatan langsung atau tak langsung. Akan tetapi, di samping mengkomunikasikan ide dan alasan, pesan-pesan persuasif Eco Pesantren Daarut

Tauhiid juga berguna untuk memotivasi audiens. Untuk melakukan itu, Eco Pesantren Daarut Tauhiid menentukan kredibilitas, menyusun kerangka argumentasi, memilih daya penarik, dan memperkuat posisi ketika mengembangkan pesan-pesan persuasifnya.

Penyampaian pesan-pesan persuasif Eco Pesantren Daarut Tauhiid yang terbaik adalah dengan menghubungkan suatu pesan dengan minat dan hasrat audiens. Untuk mengakomodasikan perbedaan individual, analisis pelanggan audiens dan kemudian susunlah suatu pesan yang dapat memenuhi kebutuhan mereka. 
Eco Pesantren Daarut Tauhiid menghormati perbedaan budaya yang ada. Budaya bukan saja akan membantu dalam memuaskan kebutuhan pelanggan, tetapi juga akan membantu bagaimana mereka mernandang Eco Pesantren Daarut Tauhiid. Langkah ini mengingat bahwa cara memberikan persuasi untuk budaya yang berbeda akan berbeda pula.

Kredibilitas Eco Pesantren Daarut Tauhiid ditentukan oleh tingkat kepercayaan dan keandalan. Kalau kredibilitas di hadapan pelanggan diragukan, mereka akan cenderung skeptis dan tidak akan menerima begitu saja setiap apa yang sampaikan. Oleh karena itu, Eco Pesantren Daarut Tauhiid mengatasi pelanggan yang memiliki sikap skeptis tersebut. Tanpa kredibilitas, upaya Eco Pesantren Daarut Tauhiid untuk melakukan persuasi akan sia-sia.

Persuasi Eco Pesantren Daarut Tauhiid terhadap pelanggan, dapat memanfaatkan emosi yang dilandasi dengan argumentasi atau dalam bentuk simpati kepada kepada pelanggan. Dalam hal ini, Eco Pesantren Daarut Tauhiid dapat menggunakan atau memilih kata-kata yang sangat berpengaruh pada emosi pelanggan, misalnya kebebasan, keberhasilan, nilai, penghargaan, kenyamanan, dan keamanan. Eco Pesantren Daarut Tauhiid gunakan kata-kata yang dapat membantu melakukan persuasi kepada audiens.

Kebanyakan pesan-pesan persuasif Eco Pesantren Daarut Tauhiid menggunakan daya pemikat dengan logika (logical appeals) dan daya pemikat yang emosional (emotional appeals) untuk melakukan persuasi pelanggan. Keseimbangan di antara keduanya bergantung pada empat faktor penting, yaitu (1) tindakan yang harapkan Eco Pesantren Daarut Tauhiid, (2) harapan pelanggan Eco Pesantren Daarut Tauhiid, (3) tingkat resistensi yang diatasi Eco Pesantren Daarut Tauhiid, dan (4) Eco Pesantren Daarut Tauhiid mampu menjual ide/gagasan dalam kewirausahaannya.

Pemikat logika Eco Pesantren Daarut Tauhiid untuk melakukan persuasi audiens, seperti membuat pengaduan (claim), selanjutnya memberikan dukungan atas pengaduan tersebut dengan memberikan alasan dan bukti-bukti yang ada.

Eco Pesantren Daarut Tauhiid menggunakan suatu alasan dari bukti-bukti spesifik menuju bukti-bukti spesifik pula. Untuk melakukan persuasi kepada karyawan agar mau menghadiri sesi perencanaan, Eco Pesantren Daarut Tauhiid menggunakan suatu analogi pertemuan komunitas, dengan membandingkan pesantren dengan komunitas kecil tempat karyawan memberikan nilai bagi anggota komunitas tersebut.

Eco Pesantren Daarut Tauhiid memberikan alasan dari bukti-bukti spesifik menuju kesimpulan umum. Untuk meyakinkan pelanggan potensial bahwa produk Eco Pesantren Daarut Tauhiid yang terbaik, dapat melaporkan hasil tes pasar yang memperlihatkan bahwa orang lebih menyenangi produk Eco Pesantren Daarut Tauhiid dibanding yang lain.

Eco Pesantren Daarut Tauhiid dilakukan dengan pemberian alasan dari yang bersifat umum untuk kesimpulan yang spesifik. Persuasi Eco Pesantren Daarut Tauhiid digunakan untuk mempengaruhi audiens dengan memberikan 
informasi dan menambah pernahaman mereka dalam berbagai hal. Berikut penjelasan Ulun Priatna tentang persuasi Eco Pesantren Daarut Tauhiid.

Eco Pesantren Daarut Tauhiid secara etis menginformasikan kepada para pelanggan yang berkaitan dengan manfaat ide, organisasi, produk, atau tindakan tertentu sehingga para pelanggan dapat mengakui betapa baiknya suatu ide, organisasi, produk, atau tindakan Eco Pesantren Daarut

Penyusunan persuasi Eco Pesantren Daarut Tauhiid tetap menjaga batasbatas permintaannya. Oleh karena itu, dalam membuat permintaan persuasif,Eco Pesantren Daarut Tauhiid memberikan perhatian khusus terhadap manfaat yang didapat baik secara langsung atau tak langsung dalam memenuhi permintaan tersebut.Pesan-pesan penjualan biasanya dikirim oleh Eco Pesantren Daarut Tauhiid yang berorientasi pada laba untuk melakukan persuasi kepada pembaca agar mengeluarkan sejurnlah uang atas produk mereka sendiri.

Salah satu tujuan Eco Pesantren Daarut Tauhiid merencanakan pesanpesan penjualan untuk memperoleh pemahaman secara menyeluruh tentang produk. Berbagai pertanyaan yang sering muncul berkaitan dengan produk Eco Pesantren Daarut Tauhiid, antara lain: apa jenis produk, bagaimana kualitas produk, bagaimana cara kerja dan manfaat produk, berapa harga produk, berapa diskon produk, bagaimana pengiriman produk, bagaimana pengepakan produk, dan berbagai atribut produk lainnya.

Data produk Eco Pesantren Daarut Tauhiid yang telah dikumpulkan, dapat membentuk citra tentang produk yang ingin dijual. Selanjutnya, Eco Pesantren Daarut Tauhiid coba lakukan cek tentang berbagai pertanyaan, seperti: siapapelanggan Eco Pesantren Daarut Tauhiid, apa manfaat yang bisa mereka peroleh, bagaimana kualitas produk yang dihasilkan, bagaimana Eco Pesantren Daarut Tauhiid memilih sarana promosi produk, dan bagaimana Eco Pesantren Daarut Tauhiid menentukan harga produk.

Penyampaian pesan-pesan persuasiveEco Pesantren Daarut Tauhiid, dimulai dengan melakukan analisis pelanggan dan memfokuskan pada bagaimana kebutuhan, minat, dan emosional mereka.Langkah selanjutnya, Eco Pesantren Daarut Tauhiid memilih poin penjualan produk atau manfaat yang paling menarik bagi pelanggan. Ketika Eco Pesantren Daarut Tauhiid melakukan komposisi pesan-pesan persuasif, pesantren fokuskan pada poin penjualan produk yang mampu menjadi daya pikat bagi pelanggan. Sebagai contoh, bagaimana masalah harga, kualitas, dan pelayanan atas penjualan produk sering kali menjadi perhatian pelanggan.

Pemahaman Eco Pesantren Daarut Tauhiid yang baik terhadap pelanggan membuat penyampaian pesan secara efektif, membantu dalam memilih perbendaharaan kata yang tepat, dan membantu dalam memilih manfaat utama dari penyampaian pesan-pesan persuasifnya.

\section{Inovasi dalam Komunikasi Bisnis pada Kewirausahaan Eco Pesantren Daarut Tauhid}


Kategorisasi inovasi pada kewirausahaan Eco Pesantren Daarut Tauhiid sebagai berikut: Pertama, asrama bambu sebagai inovasi arsitektur pesantren yang komunikatif. Arsitektur Eco Pesantren Daarut Tauhiid tetap mengangkat tema Eco Bamboo House karya arsitek Budi Faisal. Asrama santri dan rumah ketua yayasan memaksimalkan penggunaan material bambu pada bangunannya. Bangunan ini dibangun dengan keunikan pada dekoratifnya, serta unsur material, dan strukturnya sebagian besar menggunakan bahan dari bambu. Asrama bambu menjadi inovasi arsitektur pesantren yang komunikatif, karena mencerminkan ekologi sundawi.

Arsitektur yang komunikatif ini mempertegas keramahan yang dimiliki karyawan Eco Pesantren Daarut Tauhiid. Jika karyawan memproyeksikan keramahan secara verbal melalui tegur sapa, secara nonverbal melalui senyuman, maka asrama bambu mencerminkan keramahannya secara nonverbal melalui motif alamiah pada setiap dekorasinya.

Pemanfaatan keindahan arsitektur dari bambu juga digunakan pada catering seperti untuk outbond dan wisata alam. Catering untuk eksternal dikemas satu paket dengan tempat. Fasilitas tempat yang disediakan, yakni gor pesantren. Gor yang disewakan dilengkapi dengan fasilitas Masjid Rahmatan Lil Alamin. Masjid ini juga dibangun dengan konsep eco arsitecture. View gor pesantren menghadap pemandangan yang indah dengan pohon-pohon yang rindang. Sebagai ciri khas Eco Pesantren Daarut Tauhiid, dekat gor juga terdapat asrama bambu, sehingga mempertegas corak ekologi pesantren dengan eco culture. Menurut Zaenal, bambu digunakan untuk mensosialisasikan jenis material lain selain kayu untuk bahan bangunan.

Asrama dan rumah bambu di Eco Pesantren Daarut Tauhiid, dilengkapi juga oleh ornament dan perabot-perabot dengan bahan dasar dari bambu. Selain itu, terlihat pula nuansa green dengan adanya pepohonan di area pesantren yang membuatnya menyatu dengan keadaan alam sekitar berupa alam yang hijau dan luas.

Kedua, Bagi Hasil sebagai Inovasi dalam Sistem Agrobisnis. Inovasi dalam kewirausahaan Eco Pesantren Daarut Tauhiid ini menggabungkan kewirausahaan, dengan basis pertanian. Selain itu, penggabungan kepemimpinan Islam, dan wawasan lingkungan hidup dengan konsep Eco Pesantren. Agrobisnis ini dikembangkan dengan landasan kejujuran.

Zaenal melukiskan persemaian kejujuran kepada petani. Eco Pesantren Daarut Tauhiid tidak hanya mengejar keuntungan semata, tetapi juga keberkahan. Petani dibimbing untuk takut berbuat curang. Sebab jika ada kecurangan, akibatnya mengurangi keberkahan hasil panen petani. Bisa jadi kecurangannya hanya sedikit, tetapi kerugian panennya besar. Oleh karena itu, pesantren mendidik petani untuk jujur. Caranya, menanamkan rasa takut dalam jiwa petani.

Petani di Parongpong juga ada yang masih berani berbuat curang, meskipun sudah diingatkan pesantren. Pada kondisi demikian, pesantren dapat mendeteksi ketidakjujuran dari komunikasi nonverbal petani. Misalnya, menutup mulut 
dengan telapak tangan menunjukkan suatu kebohongan. Telapak tangan yang terbuka untuk menunjukkan kejujuran.

Pesantren dapat mendeteksi kecurangan atau menegaskan kejujuran orang lain dengan memperhatikan isyarat nonverbal (Zaenal, Koordinator Agrobisnis Eco Pesantren Daarut Tauhiid. Wawancara pada 20 Agustus 2015). Maka, tidaklah, mengherankan bila pengurus pesantren lebih percaya pada pesan-pesan yang disampaikan melalui isyarat nonverbal daripada pesan-pesan yang disampaikan melalui isyarat verbal.

Petani dapat saja menutup-nutupi kecurangan dengan isyarat verbal. Namun, tidak dapat sepenuhnya menutupi apa yang sedang terjadi pada dirinya karena kecurangan petani tercermin dalam ekspresi wajahnya.

Manakala wajah petani murung atau cemberut, dapat diduga bahwa ia sedang menghadapi suatu masalah, bisa jadi masalah pribadi, keluarga, atau masalah di kebunn. Komunikasi nonverbal penting artinya bagi petani dan pesantren, karena sifatnya yang efisien. Pesan nonverbal dapat disampaikan petani tanpa harus berpikir panjang, dan pihak pesantren juga dapat menangkap artinya dengan cepat.

Agrobisnis digerakkan dengan sistem bagi hasil. Setiap musim pesantren memberikan modal kepada masyarakat berupa benih dan juga pupuk. Saat tiba musim panen, masyarakat diberikan pilihan bisa menjual hasil panennya kepada bandar-bandar setempat, ke pasar, atau dijual kembali ke Eco Pesantren. Keuntungan dari penjualan hasil panen dibagi dua, $70 \%$ untuk masyarakat, dan $30 \%$ untuk pesantren. Begitu juga bila hasil panen mengalami kerugian, maka kerugiannya dibagi dua, $70 \%$ ditanggung masyarakat dan $30 \%$ ditanggung pesantren.

Jika masyarakat memperoleh hasil panen yang bagus, maka keuntungan yang diperoleh masyarakat akan lebih tinggi daripada keuntungan yang diperoleh pesantren. Sebaliknya, jika masyarakat memperoleh kerugian maka kerugian yang ditanggung masyarakat lebih tinggi daripada kerugian yang ditanggung pesantren. Oleh karena itu, masyarakat termotivasi untuk meningkatkan produktivitasnya supaya mendapat hasil panen yang bagus, sehingga memperoleh keuntungan yang tinggi.

Ketiga, penitipan dagangan sebagai inovasi warung kebersamaan. Warung Eco Pesantren diisi dengan olahan makanan yang dibuat masyarakat sekitar. Pagipagi masyarakat menitipkan dagangannya. Pihak pesantren mengkoordinir penjualannya. Sore hari masyarakat dapat mengambil hasil penjualannya. Peraturan ini membuat lingkungan pesantren tetap teratur dan masyarakat pun dapat tetap jualan dengan sistem penitipan dagangan.

Karakteristik Inovasi Eco Pesantren Daarut Tauhiid merupakan sifat dari difusi inovasi.Karakteristik inovasi Eco Pesantren Daarut Tauhiid merupakan salah satu yang menentukan kecepatan suatu proses inovasi.

Keuntungan relatif Eco Pesantren Daarut Tauhiid adalah tingkat kelebihan inovasi kewirausahaan pesantren. Inovasi Eco Pesantren Daarut Tauhiid lebih baik dari inovasi yang ada sebelumnya atau dari hal-hal yang biasa dilakukan. 
Biasanya inovasi Eco Pesantren Daarut Tauhiid diukur dari segi ekonomi, prestasi sosial, kenyamanan dan kepuasan. Semakin besar keuntungan relatif yang dirasakan oleh pelanggan, maka semakin cepat inovasi tersebut diadopsi.

Keserasian Eco Pesantren Daarut Tauhiid adalah tingkat keserasian dari suatu inovasi pesantren.ApakahEco Pesantren Daarut Tauhiid dianggap konsisten atau sesuai dengan nilai-nilai, pengalaman dan kebutuhan yang ada. Jika inovasi Eco Pesantren Daarut Tauhiid berlawanan atau tidak sesuai dengan nilai-nilai dan norma yang dianut oleh masyarakat maka inovasi baru tersebut tidak dapat diadopsi dengan mudah oleh masyarakat.

Kompleksitas Eco Pesantren Daarut Tauhiid adalah tingkat kerumitan dari suatu inovasi. Seberapa sulit Eco Pesantren Daarut Tauhiid memahami dan menggunakan inovasi. Semakin mudah inovasiEco Pesantren Daarut Tauhiid dimengerti dan dipahami oleh msyarakat, maka semakin cepat inovasi diadopsi.

\section{Evaluasi Komunikasi Bisnis pada Kewirausahaan Eco Pesantren Daarut Tauhid}

Proses evaluasi dalam komunikasi bisnis Eco Pesantren Daarut Tauhiid seperti tindakan dalam mengendarai mobil. Apabila Eco Pesantren Daarut Tauhiid mengurangi salah satu tindakan evaluasinya, maka tidak akan sampai kepada tujuan kewirausahaannya dalam keadaan terbaik. Tindakan evaluasi Eco Pesantren Daarut Tauhiid meliputi lihat, sesuaikan, belok, gas, atau rem.

Pertama, Melihat Tantangan. Eco Pesantren Daarut Tauhiid mendapatkan jalan yang lebar dari mitra bisnisnya dengan kekuatan pelayanan yang dihormati. Oleh karena itu pesantren melihat, memperhatikan, dan membaca sifat dari mitra bisnisnya. Tanpa disadari, banyak masyarakat yang bergabung menjadi mitra Eco Pesantren Daarut Tauhiid karena kemudahan yang diberikan.

Kesuksesan yang diterima Eco Pesantren Daarut Tauhiid tidak lepas dari tantangan juga. Rintangan yang dihadapi tidak dijadiukan penghalang, tetapi dijadikan tantangan, sehingga bisa memperjuangkan tujuan komunikasi bisnis pesantren.

Kedua, Menyesuaikan Kekuatan dan Kecepatan. Roda kewirausahaan berputar dengan kecepatan dan kekuatan yang tidak dapat diduga. Sehingga Eco Pesantren Daarut Tauhiid membentuk kemampuan untuk menyesuaikan diri.

Ketiga, Membelok untuk Sampai pada Tujuan. Eco Pesantren Daarut Tauhiid tidak memaksakan harus melaju dengan terus lurus, tetapi pada kondisi tertentu mengambil jalur berbelok juga. Semuanya disesuaikan dengan situasi dan kondisinya.

Ketiga, Tancap Gas Pemberdayaan Masyarakat dengan Berwirausaha. Salah satu tujuan pendirian kewirausahaan Eco Pesantren Daarut Tauhiid untuk pemberdayaan masyarakat, serta menjaga ketauhidan masyarakat supaya tidak terpengaruh mengikuti kepercayaan agama lain. Oleh karena itu, Eco Pesantren Daarut Tauhiid melaju menjadi yang tercepat melakukan pembinaan ketauhidan 
di tengah masyarakat.

Eco Pesantren Daarut Tauhiid tidak mengeluhkan kesulitan usaha yang dilakukan di depan masyarakat. Pesantren menancap gas untuk bergerak cepat melakukan persuasi untuk pemberdayaan masyarakat melalui kewirausahaan.

Keempat, Melakukan Rem untuk Mencapai Kecepatan Berwirausaha yang Bijak. Rem merupakan alat untuk menghentikan. Akan tetapi, dalam kewirausahaan Eco Pesantren Daarut Tauhiid rem merupakan alat pengatur kecepatan. Rem dalam persuasi komunikasi bisnis Eco Pesantren Daarut Tauhiid diartikan sebagai alat untuk mencapai kecepatan berwirausaha yang bijak.

Evaluasi dilakukan Eco Pesantren Daarut Tauhiid diatas sejalan dengan konsep analisis SWOT berkaitan dengan strength (kekuatan), weakness (kelemahan), opportunity (peluang) dan Threat (ancaman). Evaluasi dilakukan dalam rapat mingguan setiap hari Jumat. Evaluasi menangkap kekuatan dan kelemahan utama yang ada di dalarn kewirausahaan Eco Pesantren Daarut Tauhiid, serta menggambarkan peluang dan ancarnan yang dihadapi. (1) Kekuatan: Pengalaman dan pandanganberwirausaha Eco Pesantren Daarut Tauhiid yang mendalam. Selain itu, tujuan bisis untuk menjaga pemberdayaan dan ketauhidan masyarakat. (2) Kelernahan: Kurangnya pengecer yang dapat bekerja tatap muka dengan pelanggan untuk menghasilkankesadaran merek dan produk. (3) Peluang: Partisipasi dalam kewirausahaan Eco Pesantren Daarut Tauhiid yang sedang tumbuh; penurunan biaya produk melalui skala keekonomisan; dan kemampuan untuk mendongkrak usaha bisnis peserta kewirausahaan Eco Pesantren Daarut Tauhiid lain untuk membantu menumbuhkan pasar umum. (4) Ancaman: Persaingan masa depan/potensial dari peserta pasar yang sudah mapan.

Evaluasi kewirausahaan Eco Pesantren Daarut Tauhiid berangkat dari asumsi bahwa berbagai permasalahan yang dihadapi yayasan dapat dikelompokkan ke dalam empat unsur, yakni kekuatan, kelemahan, peluang, dan ancaman. Evaluasi ini digunakan untuk analisis terhadap kondisi kewirausahaan Eco Pesantren Daarut Tauhiid. Lalu menyeimbangkan kekuatan dan kelemahan pada lingkungan internal kewirausahaan Eco Pesantren Daarut Tauhiid dengan peluang dan ancaman dari lingkungan eksternal pesantren. Evaluasi merupakan cara untuk mengamati lingkungan bisnis eksternal dan internal.

Pertama, Analisis Lingkungan Eksternal (Peluang dan Ancaman) Kewirausahaan Eco Pesantren Daarut Tauhiid. Kewirausahaan Eco Pesantren Daarut Tauhiid mengamati kekuatan lingkungan makro yang utama dan faktor lingkungan mikro yang signifikan. Kekuatan yang mempengaruhi kemampuannya dalam menghasilkan laba. kewirausahaan Eco Pesantren Daarut Tauhiid menetapkan sistem pengamat bisnis untuk menelusuri tren dan perkembangan penting serta semua peluang dan ancaman yang berhubungan dengannya.

Pemasaran yang baik adalah seni menemukan, mengembangkan, dan menghasilkan laba dari peluang-peluang ini. Peluang bisnis adalah wilayah kebutuhan dan minat pernbeli, di mama kewirausahaan Eco Pesantren Daarut Tauhiid mempunyai kesempatan tinggi untuk memuaskan kebutuhan tersebut dengan menguntungkan. Ada tiga sumber peluang pasar. 
Sumber pertama, memasok barang yang persediaannyasedikit. Langgkah ini memerlukan sedikit bakat pemasaran, karena kebutuhannya cukup jelas. Sumber kedua, memasok produk atau jasa yang ada dengan cara yang baru atau unggul. Ada beberapa cara untuk mengungkapkan kemungkinan perbaikan produk atau jasa, yaitu:

(1) Eco Pesantren Daarut Tauhiid meminta saran dari konsumen.(2) Eco Pesantren Daarut Tauhiid membuat konsumen mendapatkan kualitas ideal produk atau layanan. (3) Eco Pesantren Daarut Tauhiid meminta konsumen memberi tahu tentang langkah-langkah mereka dalam memperoleh, menggunakan, dan menyingkirkan produk.

Metode terakhir ini menghasilkan produk atau layanan yang seluruhnya baik.Peluang dapat tersembunyi dalam berbagai wujud, dan Eco Pesantren Daarut Tauhiid benar-benar dapat menemukan wujud tersebut. Perhatikan hal-hal berikut: (a) Eco Pesantren Daarut Tauhiid menemukan kebutuhan pelanggan yang belum terpenuhi. (b) Eco Pesantren Daarut Tauhiid mengidentifikasi segmen pelanggan yang belum dilayani. (c) Eco Pesantren Daarut Tauhiid membuat proses pembelian lebih nyaman atau efisien. (d) Eco Pesantren Daarut Tauhiid memenuhi kebutuhan dengan menerima Iebih banyak informasi dan nasehat. (e) Eco Pesantren Daarut Tauhiid menyesuaikan produk atau jasa yang sebelumnya hanya ditawarkan dalam bentuk standar. (f) Eco Pesantren Daarut Tauhiid dapat memperkenalkan kemampuan baru. (g) Eco Pesantren Daarut Tauhiid mampu menghantarkan produk atau jasa dengan lebih cepat. (h) Eco Pesantren Daarut Tauhiid dapat menawarkan produk dengan harga yang jauh lebih murah.

Kedua, Analisis Lingkungan Internal (Kekuatan dan Kelemahan) kewirausahaan Eco Pesantren Daarut Tauhiid. Kemampuan Eco Pesantren Daarut Tauhiid menemukan peluang yang menarik, serta kemampuan memanfaatkan peluang tersebut merupakan dua hal yang berbeda. Setiap kewirausahaan Eco Pesantren Daarut Tauhiid mengevaluasi kekuatan dan kelernahannya. kewirausahaan Eco Pesantren Daarut Tauhiid tidak harus memperbaiki semua kelemahannya, atau sebaliknyamenyornbong-kan semua kekuatannya. Pertanyaan besarnya, apakah Eco Pesantren Daarut Tauhiid harus membatasi dirinya sendiri terhadap peluang-peluang di mana yayasan memiliki kekuatan yang diperlukan, atau mempertimbangkan peluang yang mengharuskannya menemukan atau mengembangkan kekuatan baru.

Kewirausahaan Eco Pesantren Daarut Tauhiid berjalan buruk bukan karena orang-orang tidak rnempunyai kekuatan yang diperlukan, tetapi karena mereka bekerja sama sebagai satu tim yang bukan pribumi dari Parongpong.

\section{PENUTUP}

Proses penyampaian informasi dalam komunikasi bisnis pada kewirausahaan Eco Pesantren Daarut Tauhiid dilakukan dengan keramahan, 
kesederhanaan, kesesuaian, dan keterhubungan.

Proses Persuasi dalam kewirausahaan Eco Pesantren Daarut Tauhiid diwarnai corak kebaikan dan kekuatan yang tercermin dalam karakter kedisiplinan, keberanian, kejujuran, keikhlasan, ketangguhan, dan ketawadhuan. Persuasi ini diformulasikan dengan model AIDA yang berkaitan dengan attention (perhatian), interest (minat), desire (hasrat), dan action (tindakan). Inovasi dalam kewirausahaan Eco Pesantren Daarut Tauhiid meliputi asrama bambu yang komunikatif, bagi hasil dalam sistem agro bisnis, dan penitipan dalam warung kebersamaan. Evaluasi yang dilakukan dalam kewirausahaan Eco Pesantrn Daarut Tauhiid menggunakan analisis SWOT yang disinkronkan dengan konsep mengendarai mobil, yakni lihat, sesuaikan, belok, gas, dan rem. Evaluasi dilakukan dalam rapat mingguan setiap hari Jumat. Analisis SWOT menangkap kekuatan dan kelemahan utama yang ada di dalarn kewirausahaan Eco Pesantren Daarut Tauhiid, serta menggambarkan peluang dan ancarnan yang dihadapi.

Bagi pesantren yang belum mendirikan kewirausahaan, disarankan untuk merintis usaha supaya pesantren dapat melakukan pemberdayaan masyarakat dan mengembangkan konsep dakwah kahartos jeung karaos (dimengerti dan dirasakan). Saran untuk Eco Pesantren Daarut Tauhiid, dapat mendeteksi kecurangan dari petani dengan memperhatikan isyarat nonverbal. Maka, pengurus pesantren dapat percaya pada pesan-pesan yang disampaikan melalui isyarat nonverbal daripada pesan-pesan yang hanya disampaikan melalui isyarat verbal.

\section{DAFTAR PUSTAKA}

Bovee dan Thill, Komunikasi Bisnis Edisi Kedelapan Jilid 1, dari Business Communication Eight Edition, Terjemahan oleh Doddi Prastuti, (Jakarta: Indeks, 2007).

Buchari Alma, Manajemen bisnis dan bisnis Jasa, (Bandung: Alfabeta, 2011). Carte, P dan Fox, C. Komunikasi Lintas Budaya, Terjemahan Dra. K. Anggraini, M.Si, dari Bridging The Culture Gap, (Jakarta: Indeks, 2006).

Dan B. Curtis, James J. Floyd, dan Jerry L. Winsor, Busines and Profesional

Communication, (New York: Harper Collins Publisher Inc, 2006). Djoko Purwanto, Komunikasi Bisnis, (Jakarta: Erlangga, 2011).

Eman Suherman, Business Entrepreneur, (Bandung: Alfabeta, 2010).

Ilham Prisgunanto, Komunikasi bisnisStrategi dan Taktik, (Bogor: Ghalia Indonesia, 2006).

Lexy J. Maleong, Metode Penelitian Kualitatif, (Bandung: Remaja Rosdakarya, 2009).

Mahi M. Hikmat, Metode Penelitian dalam Perspektif Ilmu Komunikasi dann Sastra, (Bandung: Graha Ilmu, 2011).

Murphy, H. A. dan Herbert, W. H, Effective Business Communication, (New York: McGraw-Hill, 1991).

Nurcholis Madjid, Bilik-bilik Pesantren; Sebuah Potret Perjalanan, Jakarta: Paramadina, 1997).

Philip Kotler dan Kevin Lane Keller, Marketing Management, Thitteenth Edition, 
A. Ningsih, A.Muhyiddin, \& I.Rosyidi

(New York: Pearson Education Inc, 2009).

Program Pascasarjana Universitas Islam Negeri Sunan Gunung Djati Bandung, Panduan Akademike Penulisan Tesis dan Disertasi, (Bandung: UIN Sunan Gunung Djati Bandung, 2013).

Sandra Oliver, Public Relations Strategy, (London: Kogan Page Ltd, 2006).

Soeganda Priyatna dan Elvinaro Ardianto, Tujuh Pilar Strategi Komunikasi Bisnis, (Bandung: Widya Padjadjaran, 2009).

Soleh Soemirat dan Elvinaro Ardianto, Dasar-dasar Public Relations, (2012, Bandung: Remaja Rosdakarya).

Suharsimi Arikunto, Prosedur Penelitian Suatu Pendekatan Praktik, Jakarta: Rineka Cipta, 2010).

Sutrisna Dewi, Komunikasi Bisnis, (Yogyakarta: Andi, 2007).

Thomas M. Harris, The Marketer's Guide to Public Relations, (1991, New York: John Wiley \& Sons).

Yosal Iriantara, Manajemen Strategis Public Relations, Jakarta: Ghalia Indonesia, 2004).

Zulkarimen Nasution, Komunikasi Pembangunan, Jakarta: Raja Grafindo Persada, 1998). 